\title{
Social capital and self-perceived need for complete denture use or exchange
}

Mayara dos Santos Camêlo Moreira ${ }^{\mathrm{a}}$, Bianca Marques Santiago ${ }^{\mathrm{a}}$, Carla Ramos de Oliveira ${ }^{\mathrm{a}}$, Thiago Isidro Vieirab ${ }^{\mathrm{b}}$ Brenna Louise Gondim ${ }^{\mathrm{b}}$, Ana Maria Gondim Valença ${ }^{\mathrm{a}}$

\begin{abstract}
Objective: To analyze self-perceived need for complete denture use or replacement in the population aged 35-44 and 65-74 years, as well as to carry out the association between that self-assessment and social capital in the municipalities of Conde and Pedras de Fogo, Paraíba.

Methods: A total of 134 adults and 54 elderlies participated in this sectional study. The outcome of interest was self-perceived need for complete denture use or replacement. Data were analyzed descriptively and association between variables was checked by means of statistical tests and regression models $(\alpha=5 \%)$.

Results: self-perceived need for denture use or replacement was observed in $61.2 \%(n=82)$ of the adults and $59.2 \%(n=32)$ of the elderlies, and it was found to be associated with the use of dentures $\left(\chi^{2}\right.$ test, $p$-value $\left.<0.05\right)$. Logistic regression revealed that education $(\mathrm{OR}=0.83, \mathrm{Cl}$ : 0.74-0.94), poor self-perceived oral health $(\mathrm{OR}=19.22, \mathrm{Cl}$ : $1.29-286.45)$ and global use of dentures $(\mathrm{OR}=0.16, \mathrm{Cl}$ : 0.07-0.40) were associated with the outcome.

Conclusion: self-perceived need for complete denture use or replacement was more frequent among adults that wore dentures in comparison to the elderlies. In addition, individuals with lower education level, unsatisfied with their oral health and denture wearers were more inclined to report needing to use or replace their complete denture.
\end{abstract}

Key words: Epidemiology, Dental Prosthesis/Use, Social Capital

\section{Capital social e autopercepção da necessidade de uso ou troca da prótese total}

\section{Resumo}

Objetivo: analisar a autopercepção da necessidade de uso ou troca de prótese total na população de 35-44 e 65-74 anos e testar sua associação com capital social nos municípios de Conde e Pedras de Fogo, Paraíba. Métodos: estudo seccional realizado com 134 adultos e 54 idosos. O desfecho de interesse foi a percepção da necessidade de uso ou troca de prótese total. Os dados foram analisados descritiva e inferencialmente para testar a associação entre as variáveis $(\alpha=5 \%)$. Resultados: a autopercepção da necessidade de uso ou troca da prótese total foi observada para $61,2 \%(n=82)$ dos adultos e $59,2 \%(n=32)$ dos idosos, estando associada ao uso de prótese dentária (Teste $\chi^{2} ; \mathrm{p}$-valor $\left.<0,05\right)$. Por regressão logística, a escolaridade $(\mathrm{OR}=0,83$; IC: 0,74-0,94), autopercepção de saúde bucal ruim (OR=19,22; IC: 1,29-286,45) e uso global de prótese dentária (OR=0,16; IC: 0,07-0,40) estiveram associadas ao desfecho.

Conclusão: a autopercepção da necessidade de uso ou troca da prótese total foi mais frequente entre os adultos que faziam uso de prótese dentária comparativamente aos idosos. Adicionalmente, indivíduos com menor escolaridade, insatisfeitos com a saúde bucal e usuários de prótese dentária foram mais propensos a relatar que necessitavam usar ou trocar prótese total.

Palavras-chave: Epidemiologia, Prótese dentária/utilização, Capital Social a Universidade Federal da Paraíba, João Pessoa,
PB, Brasil

b Public dental practice, João Pessoa, PB, Brasil
Correspondence: Mayara dos Santos Camêlo Moreira dossantosmayara@yahoo.com.br

Received: January 21, 2013 Accepted: July 6, 2015

Conflict of Interests: The authors state that there are no financial and personal conflicts of interest that could have inappropriately influenced their work.
cono

Copyright: $\odot 2014$ Moreira et al licensee EDIPUCRS

Except where otherwise noted, conten of this journal is licensed under a Creative Commons Attribution 4.0 International license. 


\section{Introduction}

Health should be considered within a social and economic background, as the influence of determinants in the health-disease process is crucial in population's health and living conditions [1]. Social determinants of health (SDH) are socioeconomic, cultural, environmental, racial, psychological and behavioral aspects influencing the occurrence of health problems. Furthermore, the distribution of health and disease in a population is associated with social status, which in turn defines the conditions of life and work of individuals and groups [2].

A number of studies have analyzed the relationship between population's health, inequalities in living conditions and the degree of establishment of bonding and associations among individuals and groups. These studies have focused on social capital as an important determinant of health [3]. So, efforts have been made in the field of collective health in order to find the determinants of health, disease and wellbeing in populations, using social capital for such a purpose.

Social capital encompasses citizenship, trust in others, cooperation and social involvement. It is related to social support networks and social support [4]. In health, social capital is considered an element with positive impact that provides a healthier life for people, reducing social exclusion and increasing longevity and self-esteem, besides playing a key role in stimulating participation of the community both in formulating public policies and in their social control $[4,5]$.

Oral health perception is an important indicator of health as it summarizes objective health condition, subjective responses, values and cultural expectations [6]. Oral health perception and its relationship with other aspects of human life should be further investigated even as the way how these relationships can guide behaviors and attitudes [7].

Tooth loss affects a biological condition (chewing) and a psychological condition (self-esteem) and brings about deficiencies to the daily lives of individuals, including difficulties of relating socially [8]. This condition is the result of several determinants such as poor living conditions, low supply and coverage of dental services and a mutilating care model [9]. Nonetheless, tooth loss can be overcome by rehabilitation with dental prosthesis, whose availability is still limited by economic issues [8].

A small number of Brazilian studies have made systematic use of the concept of social capital as an explanatory model for health-disease patterns in oral health [4]. In the studies associating social capital to oral health, the variables dental trauma, tooth decay and self-perceived oral health are measured as primary outcomes. The association between social capital and oral health-related outcomes has not been studied yet in northeastern Brazil, and also there have been no studies on the specific association between social capital and perceived need for denture use in any country. Thus, the aim of this study was to analyze the self-perceived need for complete denture use or replacement in the population aged 35-44 and 64-74 years, as well as to investigate its association with social capital in the municipalities of Pedras de Fogo and Conde, located in the state of Paraíba, Brazil.

\section{Methods}

The participation of individuals in this study was voluntary and those who agreed to participate signed an informed consent form. This study was approved by the Institutional Review Boards of the State Health Department of Paraíba (CAAE - 0001.0.349.000-09) and Lauro Wanderley University Hospital of Federal University of Paraíba (UFPB) (CAAE - 2147.0.000.126-10).

This is a population-based sectional study conducted in the municipalities of Conde and Pedras de Fogo, Paraíba, Brazil. The municipality of Conde has 21,400 inhabitants and a Human Development Index (HDI) of 0.61 [10]. With regard to oral health coverage by the city public service, there are nine (9) oral health teams and one (1) Center for Dental Specialties (CDS) [11]. The municipality of Pedras de Fogo has about 27,032 inhabitants and an HDI of 0.57 [10], and its oral health coverage consists of eleven (11) oral health teams and one (1) CDS [11].

Random cluster sampling was performed in two stages: drawing of census tracts and homes, following the same criteria used in the national epidemiological survey SBBrasil 2010. Data were collected in households by three teams including an examiner and a recorder properly trained and calibrated on the basis of the criteria established by the SBBrasil 2010 [12].

The age groups included in this study were: 35 to 44 years (adults) and 65-74 years (elderly). The subjects were examined for dental caries, periodontal conditions and use and need for dentures, using the examination form recommended by the Project SBBrasil 2010.

In addition to dental examinations, we also carried out interviews using the SBBrasil 2010 questionnaire, and another questionnaire of social capital developed based on the literature, validated and previously tested in the Brazilian population obtaining adequate internal consistency, as the Cronbach's alpha coefficient was greater than 0.70 [13].

Participants were surveyed about socioeconomic factors, use of dental services, referred oral morbidity, self-perceived oral health, and social capital in its five dimensions (social trust, social control, level of "empowerment", political efficacy and safety in the neighborhood).

In order to assess the self-perceived need for denture use or replacement, which was considered the outcome of interest in the present study, we used specifically the question \#15 from the SBBrasil 2010 questionnaire: "Mr./ Mrs., do you consider you need to wear a complete denture or replace the one you are currently using?".

All data were subjected to descriptive analysis and the association between variables was analyzed by means of statistical tests (Chi-square and Fisher's exact test) and by regression models, adopting a significance level of 5\%.

For modeling, we firstly undertook bivariate analyzes to identify the association between each of the independent 
variables with the outcome by calculating the odds ratio (OR) and its confidence interval (95\%). Variables with a $\mathrm{p}$-value $\leq 0.20$ at this stage were included in the multivariate analysis.

Multivariate logistic regression was performed by the stepwise backward method to select the risk factors in different blocks. The first block consisted of variables measured at the area level: global social capital and its five dimensions (census tracts were categorized into low, medium and high according to the 33rd and 66th percentiles). The second block included the variables measured at the individual level, such as socioeconomic issues (family income, education and type of water supply). And a third and last block including proximal variables, also measured individually, was composed of demographic characteristics (gender and race), experience of dental pain and self-perceived oral health (assessment of own health and perceived need for dental treatment), and global use and need for dentures.

\section{Results}

Among the 188 individuals (134 adults and 54 elderlies) participating in this study, $50.0 \%(n=67)$ of the adults examined and $50.0 \%(\mathrm{n}=27)$ of the elderlies wore dentures. As to the type of prosthesis, $41.0 \%(n=55)$ and $5.2 \%(n=7)$ of the adults wore partial upper and lower denture, respectively; and $8.2 \%(\mathrm{n}=11)$ and $4.5 \%(\mathrm{n}=6)$ wore complete upper and lower denture, respectively. Among the elderlies, we observed that $20.4 \%(\mathrm{n}=11)$ wore partial upper denture and $14.8 \%(\mathrm{n}=8)$ wore partial lower denture; complete upper and lower dentures were used by $29.6 \%(\mathrm{n}=16)$ and $20.4 \%$ $(\mathrm{n}=11)$ of the subjects, respectively.
In the municipalities studied, $61.2 \%(\mathrm{n}=82)$ of the adults and $59.2 \%(\mathrm{n}=32)$ of the elderlies reported needing to use or replace their complete dentures, representing $60.6 \%(n=114)$ of the total number of individuals interviewed.

By crossing the data about self-perceived need for complete denture use or replacement with the use of denture among adults and elderlies (Table 1), we observed a statistically significant association for the group of adults, but not for the elderlies ( $p$-value $>0.05$ ).

The same analyses were carried out between selfperceived denture use or replacement and need for denture. No significant association was observed in the group of adults according to the chi-square test. When this same association was investigated in the age group of elderlies according to the Fisher's exact test, there was also no statistically significant association ( $p$-value $>0.05$ ) (Table 2 ). The results also revealed that the three respondents who did not know or did not answer the question about selfperception were in need of dentures.

With regard to the outcome, bivariate analysis indicated no significant association with any of the variables in the area (block 1); instead, all the variables in block 2 (education, family income and type of water supply) were found to be associated. Of the proximal variables (block 3), selfperceived oral health, perceived need for dental treatment and global use of denture proved to be associated with the outcome (Table 3 ).

The results of the hierarchical logistic regression (Table 4) pointed to education as the only variable in block 2 to remain associated with self-perceived need for denture use or replacement. Of the individual variables, only selfperceived oral health and global use of denture remained associated with the outcome.

Table 1. Distribution in percentages and absolute numbers of the use of dentures and self-perceived need for complete denture use or replacement among adults $(p$-value $=0.000)$ and elderly ( $p$-value $=0.695)$.

\begin{tabular}{l|c|c|c|c|c|c|c|c|}
\hline \multirow{2}{*}{$\begin{array}{l}\text { Self-perceived need for complete } \\
\text { denture use or replacement }\end{array}$} & \multicolumn{4}{c|}{ Adults } & \multicolumn{3}{c}{ Elderly } \\
\cline { 2 - 9 } & Use denture & Do not use denture & \multicolumn{2}{c}{ Use denture } & \multicolumn{2}{c}{ Do not use denture } \\
\hline NO & $\%$ & $\mathbf{n}$ & $\%$ & $\mathbf{n}$ & $\%$ & $\mathrm{n}$ & $\%$ & $\mathrm{n}$ \\
YES & 30.0 & 15 & 70.0 & 35 & 47.6 & 10 & 52.4 & 11 \\
Did not know or did not answer* & 63.4 & 32 & 36.6 & 30 & 53.1 & 17 & 46.9 & 15 \\
\hline Chi-square test; * Category excluded from the test. & - & - & 1.5 & 2 & - & - & 1.8 & 1 \\
\hline
\end{tabular}

Table 2. Distribution in percentages and absolute numbers of the need for dentures and self-perceived need for complete denture use or replacement among adults $(p$-value $=0.814)$ and elderly $(p$-value $=0.200$ )

\begin{tabular}{l|c|c|c|c|c|c|c|c|c|}
\hline \multirow{2}{*}{$\begin{array}{l}\text { Self-perceived need for complete } \\
\text { denture use or replacement }\end{array}$} & \multicolumn{4}{|c}{ Adults } & \multicolumn{4}{c}{ Elderly $^{\ddagger}$} \\
\cline { 2 - 10 } & \multicolumn{2}{|c|}{ Need denture } & Do not need denture & Need denture & Do not need denture \\
\hline NO & $\%$ & $\mathbf{n}$ & $\%$ & $\mathbf{n}$ & $\%$ & $\mathbf{n}$ & $\%$ & $\mathbf{n}$ \\
YES & 88.0 & 44 & 12 & 6 & 81.0 & 17 & 19.0 & 4 \\
Did not know or did not answer* & 86.6 & 71 & 13.4 & 11 & 93.8 & 30 & 6.3 & 2 \\
\hline
\end{tabular}

${ }^{+}$Chi-square test; ${ }^{\ddagger}$ Fisher's exact test; * Category excluded from the test. 
Table 3. Crude association of independent variables with the perceived need for complete denture use or replacement among adults and elderlies in the municipalities of Conde and Pedras de Fogo $(n=185)$.

\begin{tabular}{|c|c|c|c|c|}
\hline & Perc & ed for comp & ire use & ment \\
\hline & $\begin{array}{c}\text { Yes } \\
n=114\end{array}$ & $\begin{array}{c}\text { No } \\
n=71\end{array}$ & OR & Cl 95\% \\
\hline Block 1 & & & & \\
\hline Social Capital, n (\%) & & & & \\
\hline Low & $41(36.0)$ & 27 (38.0) & 1 & \\
\hline Intermediate & $35(30.7)$ & $16(22.5)$ & 1.44 & $0.67-3.10$ \\
\hline High & 38 (33.3) & $28(39.4)$ & 0.89 & $0.45-1.78$ \\
\hline Social Trust, n (\%) & & & & \\
\hline Low & $44(38.6)$ & $23(32.4)$ & 1 & \\
\hline Intermediate & 36 (31.8) & $26(36.6)$ & 0.72 & $0.45-1.48$ \\
\hline High & $34(29.8)$ & $22(31.0)$ & 0.81 & $0.39-1.69$ \\
\hline Social Control, n (\%) & & & & \\
\hline Low & $43(37.7)$ & $22(31.0)$ & 1 & \\
\hline Intermediate & 39 (34.2) & $28(39.4)$ & 0.71 & $0.35-1.44$ \\
\hline High & $32(28.1)$ & $21(29.6)$ & 0.78 & $0.37-1.65$ \\
\hline Empowerment, n (\%) & & & & \\
\hline Low & $40(35.1)$ & $24(33.8)$ & 1 & \\
\hline Intermediate & $43(37.7)$ & 30 (42.3) & 0.86 & $0.43-1.71$ \\
\hline High & $31(27.2)$ & $17(23.9)$ & 1.09 & $0.50-2.38$ \\
\hline Safety in the neighborhood, $\mathrm{n}(\%)$ & & & & \\
\hline Low & $40(35.1)$ & $21(29.6)$ & 1 & \\
\hline Intermediate & $24(21.1)$ & $17(23.9)$ & 0.74 & $0.33-1.67$ \\
\hline High & $50(43.9)$ & $33(46.5)$ & 0.79 & $0.40-1.58$ \\
\hline Political Efficacy, n (\%) & & & & \\
\hline Low & $43(37.7)$ & $26(36.6)$ & 1 & \\
\hline Intermediate & $29(25.4)$ & 17 (23.9) & 1.03 & $0.48-2.32$ \\
\hline High & $42(36.8)$ & $28(39.4)$ & 0.91 & $0.48-1.79$ \\
\hline Block 2 & & & & \\
\hline Education, mean (standard-deviation) $^{+}$ & $4.41(2.92)$ & $6.13(4.84)$ & 0.89 & $0.82-0.97^{\star}$ \\
\hline Family Income, $\mathrm{n}(\%)^{\ddagger}$ & & & & \\
\hline Until 250 Brazilian reais & $8(7.8)$ & $5(7.9)$ & 1 & \\
\hline Between 251 and 500 Brazilian reais & $36(35.0)$ & $21(33.3)$ & 1.07 & $0.31-3.70$ \\
\hline From 501 to 1500 Brazilian reais & $54(52.4)$ & $28(44.4)$ & 1.20 & $0.36-4.03$ \\
\hline Above 1501 Brazilian reais & $5(4.9)$ & $9(14.3)$ & 0.35 & $0.07-1.66^{\star}$ \\
\hline Type of Water Supply, $\mathrm{n}^{\S}(\%)$ & & & & \\
\hline Well & $13(11.5)$ & $4(5.6)$ & 1 & \\
\hline Piped water outside the home & $9(8.0)$ & $7(9.9)$ & 0.47 & $0.14-1.50^{*}$ \\
\hline Piped water inside the home & $91(80.5)$ & $60(84.5)$ & 0.40 & $0.09-1.76$ \\
\hline Block 3 & & & & \\
\hline Gender, n (\%) & & & & \\
\hline Female & $80(70.2)$ & $53(74.6)$ & 1 & \\
\hline Male & $34(29.8)$ & $18(25.4)$ & 1.25 & $0.64-2.44$ \\
\hline Race, n (\%) & & & & \\
\hline White/Yellow/Indigenous & $28(24.6)$ & $22(31.0)$ & 1 & \\
\hline Black & $12(10.5)$ & $8(11.3)$ & 1.18 & $0.41-3.38$ \\
\hline Brown (mixed-race) & 74 (64.9) & $41(57.7)$ & 1.42 & $0.72-2.79$ \\
\hline Dental Pain, n (\%)\# & & & & \\
\hline Yes & $29(26.1)$ & $15(21.1)$ & 1 & \\
\hline No & $82(73.9)$ & $56(78.9)$ & 0.76 & $0.37-1.54$ \\
\hline Self-perceived Oral Health, n (\%) & & & & \\
\hline Very satisfied / Satisfied & $29(25.4)$ & 39 (54.9) & 1 & \\
\hline Neither satisfied nor unsatisfied & $16(14.0)$ & $12(16.9)$ & 1.79 & $0.74-4.36^{\star}$ \\
\hline Unsatisfied / Very unsatisfied & $69(60.5)$ & $20(28.2)$ & 4.64 & $2.32-9.27^{\star}$ \\
\hline Perceived Need for Dental Treatment, $n$ & & & & \\
\hline Yes & $97(85.1)$ & $53(75.7)$ & 1 & \\
\hline No & $17(14.9)$ & $17(24.3)$ & 0.55 & $0.26-1.16^{\star}$ \\
\hline Global Use of Denture, n (\%) & & & & \\
\hline Yes & $69(60.5)$ & $25(35.2)$ & 1 & \\
\hline No & $45(39.5)$ & $46(64.8)$ & 0.35 & $0.19-0.66^{\star}$ \\
\hline Global Need for Denture, n (\%) & & & & \\
\hline Yes & $101(88.6)$ & $61(85.9)$ & 1 & \\
\hline No & $13(11.4)$ & $10(14.1)$ & 0.78 & $0.32-1.90$ \\
\hline
\end{tabular}

$\mathrm{n}^{+}=161 ; \mathrm{n}^{\ddagger}=166 ; \mathrm{n}^{\S}=184 ; \mathrm{n}^{\sharp}=182 \mathrm{OR}$, Odds Ratio; Cl, Confidence Interval; * $\mathrm{p}$-value $<0.20$ 
Table 4. Adjusted logistic regression analysis between self-perceived need for complete denture use or replacement and the independent variables.

\begin{tabular}{|c|c|c|}
\hline Independent variables & Adjusted OR & $\mathrm{Cl} 95 \%$ \\
\hline \multicolumn{3}{|l|}{ Block 2} \\
\hline Education & 0.84 & $0.75-0.94^{\star}$ \\
\hline \multicolumn{3}{|l|}{ Family Income } \\
\hline Until 250 Brazilian reais & 1 & \\
\hline Between 251 and 500 Brazilian reais & 1.66 & $0.43-6.33$ \\
\hline From 501 to 1500 Brazilian reais & 2.17 & $0.57-8.21$ \\
\hline Above 1501 Brazilian reais & 0.84 & $0.15-4.80$ \\
\hline \multicolumn{3}{|l|}{ Type of Water Supply } \\
\hline Well & 1 & \\
\hline Piped water outside the home & 0.34 & $0.70-1.67$ \\
\hline Piped water inside the home & 0.37 & $0.05-2.50$ \\
\hline \multicolumn{3}{|l|}{ Block 3} \\
\hline \multicolumn{3}{|l|}{ Self-perceived Oral Health } \\
\hline Very Satisfied / Satisfied & 1 & \\
\hline Neither satisfied nor unsatisfied & 1.75 & $0.56-5.44$ \\
\hline Unsatisfied / Very Unsatisfied & 7.64 & $2.97-19.67^{\star}$ \\
\hline \multicolumn{3}{|l|}{ Perceived Need for Dental Treatment } \\
\hline Yes & 1 & \\
\hline No & 0.42 & $0.13-1.35$ \\
\hline \multicolumn{3}{|l|}{ Global Use of Denture } \\
\hline Yes & 1 & \\
\hline No & 0.17 & $0.07-0.40^{\star}$ \\
\hline
\end{tabular}

$\mathrm{OR}=$ Odds Ratio; $\mathrm{Cl}=$ Confidence Interval; ${ }^{*} \mathrm{p}$-value $<0.05$.

\section{Discussion}

Self-assessment of oral health apparently contrasts with clinical features, because people usually have a positive view in relation to their health, even if they are presented with an unsatisfactory condition [6]. The matching between clinical examination and self-assessment occurs in more severe painful and aesthetic cases, whereas other dental problems are generally underestimated [14]. This explains the results found in this study regarding the comparison between the perception of the need for complete denture use or replacement and data on the use and need for dentures. Among the adults who responded negatively to this question, about $88.0 \%$ were in need of dentures when clinically checked. As for the elderlies whose answers were no in the inquiry, $81 \%$ were in need of dentures. In addition, according to the examiners, those adults and elderlies who did not answer or did not know how to answer such a question were in need of dental prosthesis.

In this study, we observed that the association between the use of denture and self-assessment of complete denture use or replacement was considered statistically significant for the group of adults. The same was not observed among the elderlies, probably because this group presents with different expectations regarding oral health and therefore do not realize or do not consider that they need a new denture due to age, lack of pain and discomfort, financial cost and difficulty in getting access to the service. For the dependent variable need for denture, there was no significant association between the explanatory variables and the outcome.

The perception of good oral health is the factor that most influences the idea either of not needing dental treatment [15] or of not needing to use denture. Perhaps this fact may explain why there was no association between self-perceived need for use or replacement and the factual need observed on clinical examination, both in the bivariate analysis and in the logistic regression model.

A study by Matos and Lima-Costa [15] showed that a better perception of oral health was associated with the number of existing teeth among the elderlies. Contrary to expectations, the aged who had between 1 and 19 teeth rated their oral health worse than did those who had no teeth. The explanation for this fact lies in the quality of the remaining teeth, which often generate pain or dissatisfaction with chewing and aesthetics.

Oral health is understood as being intrinsically related to general health, and in some testimonials it is perceived as beyond the biological issues, extrapolating the dental clinic, since it might be associated by some with communication skills and social contacts [16].

Silva and Castellanos Fernandes [6] assessed selfperceived oral health status among elderlies as well as the clinical, subjective and sociodemographic factors affecting their perception. Based on the results, it can be affirmed that people used different criteria from those used by the dentist to assess their oral condition. Perceived oral health was also found to be related to the social environment in which one lives and to the variables that indicate the need for treatment.

Despite the fact that our outcome of interest was different from that of the aforementioned study, we can consider its relationship with self-perceived oral health, allowing some comparisons with the previously mentioned study. Unlike observed by those authors, the perceived need for denture use or replacement was not associated with any of the variables related to social environment (social capital and its five dimensions), nor with the need for denture assessed by clinical examination.

It is pointed out the difficulty of comparing the data from this study with those of other populations due to lack of studies in the literature assessing an outcome specifically related to denture use or replacement. The majority of studies found rated self-perceived oral health as excellent / good, fair, poor or very poor. Among the studies that associated social capital with oral health the main outcomes were: tooth decay, trauma and reported dental health.

The studies by Patussi [13], Allegretti [17] and Aida [18,19] associated social capital with tooth decay and trauma, pain of dental origin and reported oral health, respectively. All outcomes were significantly associated with variables related to social capital. Unlike, in the present study, social capital and its five dimensions were not found to be associated with the perceived need for denture use or replacement.

Moyses et al. [20] analyzed social capital in relation to dental trauma. The component physical environment 
had a strong relationship with dental trauma, as well as the component related to social public policies; however, the component social cohesion was not significantly associated with dental trauma. Patussi et al [21] investigated the relationship between homicide rate, income inequality and social cohesion with dental caries. The findings revealed that social cohesion indicators were not associated with caries. Nevertheless, there was a tendency to lower homicide rates in areas with low levels of tooth decay, and income inequality proved to be strongly associated with high levels of tooth decay. These studies corroborate the findings presented herein, because despite these did not show any association with social capital, which is directly related to social cohesion, we observed associations with other outcomes, such as: education, self-perceived oral health and global use of denture, regardless the effect of confounding variables.

Like all epidemiological research, this study has some shortcomings such as the fact of being a cross-sectional investigation in which data collection regarding the outcome and exposures is performed only once, limiting the possibility of causal inference [22] between the independent variables and self-perceived need for complete denture use or replacement.

Nevertheless, the approach of social capital in studies of oral health is relatively new, especially when trying to associate it with self-assessment of denture use or replacement. Thus, the novelty of this study is highlighted by addressing a subject of increasing concern in social epidemiology and by using as parameter the criteria of the SBBrasil 2010 epidemiological survey.

The results obtained in this study point to the importance of incorporating contextual variables in the analysis of oral health determinants. Further studies involving this issue and encompassing a greater number of municipalities, census tracts or neighborhoods are now suggested.

\section{Conclusion}

Self-perceived need for complete denture use or replacement was reported by $61.2 \%$ of adults and $59.2 \%$ of elderlies and was found to be associated with the use of denture. Individuals with lower education level, unsatisfied with their oral health and denture wearers were more inclined to report needing to use or replace their complete denture. Nevertheless, there was no association between self-perceived need for complete denture use or replacement and social capital.

\section{References}

1. Junqueira S R, Frias A C, Zilbovicius C. Atualização clínica em odontologia São Paulo: Artes Médicas; 2004

2. CNDSS, Comissão Nacional sobre Determinantes Sociais da Saúde As Causas Sociais das Iniquidades em Saúde no Brasil. Rio de Janeiro: Fiocruz; 2008

3. Buss P M, Pellegrini A F. A Saúde e seus Determinantes Sociais. Rev Saúde Coletiva 2007; 17: 77-93.

4. Pattussi M P. Moyses S J, Junges J R, Sheiham A. Social capital and the research agenda in epidemiology. Cad Saúde Pública 2006; 22: 1525-46.

5. Bastos F A, Santos E, Tovo M F. Capital Social e Sistema Único de Saúde (SUS) no Brasil. Saúde soc 2009; 18:177-188

6. Silva S R C, Castellanos Fernandes R A. Autopercepção das condições de saúde bucal por idosos. Rev Saúde Pública 2001; 35: 349-355

7. Benedetti B T R et al. Idosos de Florianópolis: autopercepção das condições de saúde bucal e utilização de serviços odontológicos. Ciên. Saúde Coletiva 2007; 12: 1683-1690.

8. Ferreira A A A, Piuvezam G, Werner C W A, Alves M S C. A dor e a perda dentária: representações sociais do cuidado à saúde bucal. Ciênc saúde coletiva 2006; 11: 211-218.

9. Brasil, Ministério da Saúde. A Política Nacional de Saúde Bucal do Brasil:registro de uma conquista histórica. Brasília: Ministério da Saúde 2006:31-36.

10. IBGE. Instituto Brasileiro de Geografia e Estatística. Acesso em 03 de setembro de 2012. Disponível em http://www.censo2010.ibge.gov.br/ resultados_do_censo2010.php

11. Brasil, Ministério da Saúde. Departamento de informática do SUS. Acesso em: 10 de setembro de 2012. Disponível em: http://www2.datasus.gov. br/DATASUS/index.php.

12. Brasil, Ministério da Saúde. Secretaria de Políticas de Saúde. Departamento de Atenção Básica. Área Técnica de Saúde Bucal. Projeto SBBrasil 2010 - Pesquisa Nacional de Saúde Bucal. Manual de Calibração de Examinadores. Brasília: Ministério da Saúde; 2010: 21

13. Pattussi M P. Neighbourhood social capital and oral health in adolescents. (Tese). Inglaterra: Departamento de Epidemiologia e Saúde Pública, Universidade de Londres; 2004

14. Narvai P C, Frazão P. Saúde Bucal no Brasil: muito além do céu da boca. Rio de Janeiro: Fiocruz; 2008

15. Matos D L, Lima-Costa M F. Auto-avaliação da saúde bucal entre adultos e idosos residentes na Região Sudeste: resultados do Projeto SB-Brasil, 2003. Cad Saúde Pública 2006; 22:1699-1707.

16. Reis S C G B, Marcelo V C. Saúde bucal na velhice: percepção dos idosos, Goiânia, 2005. Ciênc. saúde coletiva 2006; 11: 191-199.

17. Alegretti, A. C. V. Capital Social e a sua relação com a saúde bucal. (Tese) Curitiba (PR): Pontifica Universidade Católica do Paraná; 2007.

18. Aida J, Hanibuchi T, Nakade M, Hirai H, Osaka K, Kondo K. The different effects of vertical social capital and horizontal social capital on denta status: a multilevel analysis. Soc Sci Med 2009; 69:512- 518.

19. Aida J, Kuriyama S, Ohmori-Matsuda K, Hozawa A, Osaka K, Tsuji I. The association between neighborhood social capital and self-reported dentate status in elderly Japanese - The Ohsaki Cohort 2006 Study. Community Dent Oral Epidemiol 2011; 39: 239-249

20. Moyses S J, Moyses S T, Mccarthyb M, Sheihamb A. Intra-urban differentials in child dental trauma in relation to Healthy Cities policies in Curitiba. Brazil Health Place 2006; 12:48-64

21. Pattussi M P, Marcenes W, Croucher R, Sheiham A. Social deprivation income inequality, social cohesion and dental caries in Brazilian school children. Soc Sci Med 2001; 53:915-25.

22. Medronho R A, Bloch K V, Luiz R R, Werneck G L. Epidemiologia. 2.ed São Paulo: Atheneu; 2009 